\title{
Health advocacy by nurses in the Family Health Strategy: barriers and facilitators
}

\author{
Advocacia em saúde por enfermeiros na Estratégia Saúde da Família: barreiras e facilitadores \\ Acción política de enfermeros en Estrategia Salud de la Familia: barreras y facilitadores
}

\begin{abstract}
Aline Belletti Figueira', Edison Luiz Devos Barlem', Simone Coelho Amestoy", Rosemary Silva da Silveira', Jamila Geri Tomaschewski-Barlem', Aline Marcelino Ramos'

' Universidade Federal de Rio Grande, Center of Health Sciences, Postgraduate Program in Nursing. Rio Grande, Rio Grande do Sul, Brazil.

"Universidade Federal da Bahia, Center of Health Sciences, Postgraduate Program in Nursing. Salvador, Bahia, Brazil.
\end{abstract}

\section{How to cite this article:}

Figueira AB, Barlem ELD, Amestoy SC, Silveira RS, Tomaschewski-Barlem JG, Ramos AM. Health advocacy by nurses in the Family Health Strategy: barriers and facilitators. Rev Bras Enferm [Internet]. 2018;71(1):57-64. DOI: http://dx.doi.org/10.1590/0034-7167-2016-0119

Submission: 04-06-2016 Approval: 02-02-2017

\section{ABSTRACT}

Objective: Identify the barriers and facilitators of health advocacy to users delivered by nurses from the Family Health Strategy. Method: Qualitative study carried out with nurses from the Family Health Strategy of a city in the south of Brazil. Study participants were 15 nurses, who were interviewed. The content of the interviews was recorded, transcribed and analyzed in the light of the discursive text analysis. Results: Two categories emerged, one about the lack of organization at the workplace, bureaucracy and limitations to professional work in health environments, and another about the facilitating aspects to exercise advocacy both individually and collectively. Conclusion: When nurses, provided with technical, scientific and relational knowledge, are empowered to make decisions, they are not only supported by other professionals at work but also develop actions of health advocacy to users, thus qualifying the care delivered.

Descriptors: Health Advocacy; Primary Health Care; Nursing; Integrality in Health; Power.

\section{RESUMO}

Objetivo: Identificar as barreiras e facilitadores da advocacia em saúde dos usuários por enfermeiros da Estratégia Saúde da Família. Método: Estudo qualitativo realizado com enfermeiros da Estratégia Saúde da Família em uma cidade no sul do Brasil. Participaram 15 enfermeiros mediante uso de entrevistas gravadas, transcritas e analisadas à luz da análise textual discursiva. Resultados: Emergiram duas categorias, uma discorrendo sobre a falta de organização do trabalho, da burocracia e das limitações para atuação profissional nos ambientes de saúde e outra sobre os aspectos facilitadores para o exercício da advocacia de forma individual e coletivamente. Conclusão: Quando o enfermeiro, imbuído dos saberes técnicos, científicos e de relacionamento, desenvolve sua autonomia na tomada de decisões, além de contar com o apoio de outros profissionais no trabalho, consegue desenvolver ações de advocacia em saúde aos usuários e, assim, qualifica o cuidado prestado.

Descritores: Advocacia em Saúde; Atenção Básica a Saúde; Enfermagem; Integralidade em Saúde; Poder.

\section{RESUMEN}

Objetivo: Identificar las barreras y facilitadores de la acción política en salud de los usuarios por parte de enfermeros de Estrategia Salud de la Familia. Método: Estudio cualitativo realizado con enfermeros de Estrategia Salud de la Familia en ciudad del Sur de Brasil. Participaron 15 enfermeros mediante entrevistas grabadas, transcriptas y analizadas por análisis textual discursivo. Resultados: Surgieron dos categorías, una discurriendo sobre falta de organización del trabajo, la burocracia y las limitaciones de actuación profesional en ámbitos sanitarios, y otra sobre aspectos facilitadores para el ejercicio de la acción política de modo colectivo e individual. Conclusión: Cuando el enfermero, poseedor de conocimientos técnicos, científicos y de relación, desarrolla su autonomía para toma de decisiones, contando con el apoyo de otros colegas profesionales. Consigue desarrollar acciones políticas en salud para los usuarios, calificando así la atención brindada.

Descriptores: Defensa de la Salud; Atención Primaria de Salud; Enfermería; Integralidad en Salud; Poder. 


\section{INTRODUCTION}

Primary Health Care (PHC) provides to professional nurses a promising work space to develop community-oriented actions on health promotion and disease prevention. In addition, it expands the insertion of nurses, who usually take on the frontline in relation to other health professionals when they develop care, administrative and educational activities crucial to consolidate and strengthen the Family Health Strategy (FHS) in the scope of the Brazilian Unified Health System (SUS) ${ }^{(1)}$.

The FHS, in turn, recommends the $\mathrm{PHC}$ reorganization and the consolidation of the SUS principles, giving priority to actions aimed to promote, protect and recover health in a comprehensive and consistent way, focusing care on family health, understood in the light of its physical and social environment ${ }^{(2-3)}$. In the FHS nurses serve as mediators in the structural and functional reorganization of the service, in the micro/macro-political changes of the healthcare system to provide it with an important social and historical trait, and also enable advances to the category and the social building of health ${ }^{(4)}$.

In the light of the FHS work, nurses take on the role of enabling agents so that individuals, families and groups can develop skills and abilities to be consciously empowered in health issues, and be capable of promoting the exercise of citizenship ${ }^{(5)}$. Nurses should try to exercise health advocacy at different stages of interaction since this is a core component of the nursing practice ${ }^{(6-7)}$.

In a broader view, health advocacy may comprise different dimensions such as to communicate, inform, educate, protect, talk about, build sound relationship/link, and also keep the focus on social issues ${ }^{(8)}$ through different actions developed by nurses on behalf of users and the community. In the FHS context, health advocacy is perceived as an integral part of the professional work of nurses to promote the users' wellbeing and empower them ${ }^{(9-10)}$.

Health advocacy is not limited to the user-nurse relationship. It concerns a triad: nurses, users and other professionals who make up the multiprofessional health team. Therefore, in addition to performing their care activities with excellence, nurses are expected to maximize the situations that lead them to work as political agents, pursuing changes as advocators of the users' and community's health ${ }^{(11)}$. This political view of nurses supports the work process innovation, advocating for individual and collective health ${ }^{(12)}$. This practice should be permanently developed in PHC.

Thus, healthcare practices should be strengthened through the work of nurses jointly with other healthcare professionals and users to build accountability plans and seek comprehensiveness in healthcare and advocacy for the right to health ${ }^{(11)}$. In the FHS, when nurses work to improve the community's quality of life they also aim to advocate for the users' health, fostering their empowerment as agents of their own health ${ }^{(12-13)}$.

Here, empowerment refers to building responsible organizations and communities through a process in which the individual takes on control over his/her life and democratically participates in the everyday life through different collective arrangements, and is skilled to criticize and change the environment. It should comprise methods that enable the full achievement of the users' rights, used as a way to foster health promotion, and individual and collective actions that entail efficient results ${ }^{(14)}$.

Advocacy for users as a subject of actions is closely related to power and empowerment. Power, understood as something inherent to autonomy, an individual need to manage physical and social demands, or a relational building of actions and reactions capable of delegating representation to someone ${ }^{(15)}$. Considering the aforementioned, the research issue was the lack of knowledge about the barriers and facilitators of health advocacy of users by FHS nurses.

\section{OBJECTIVE}

The objective of this study was to identify the barriers and facilitators of health advocacy of users by nurses working in the Family Health Strategy.

\section{METHOD}

\section{Ethical aspects}

Ethical aspects were fully complied, and the project was approved by the local ethics committee. This article is part of the macro-project named "Advocacia do paciente e coping na enfermagem: possibilidade de exercício do poder mediante vivências de sofrimento moral", process $\mathrm{CNPq}$ 474761/2012-6.

\section{Study type}

This is a qualitative, descriptive and exploratory study.

\section{Methodological procedures}

\section{Study setting}

The study comprised nurses working in the FHS of a municipality with 210,000 inhabitants in the south of Brazil. The city has 32 primary health care (PHC) units of which 19 have FHS teams and 13 follow the traditional PHC model.

\section{Data source}

The study participants were 15 nurses selected through snowball sampling. Based on previous knowledge of the primary health care units and workers in the investigated municipality, emphasizing the education links previously established by the researchers' university, a nurse renowned for advocating for users was identified and selected to be interviewed. After the interview, he was asked to indicate another nurse with the features required to the study, i.e., being renowned for advocating for users and so on, until the respondents' possibilities of nominating new participants were exhausted ${ }^{(16)}$.

The inclusion criteria were as follows: being a nurse and working in the FHS for at least six months, being this the minimum length for professionals to fit into the working environment. The study disregarded nurses on vacation or on leave. In this study, participants were identified by the letter $E$ and a sequential number (E1 to E15), following the order of interviews. 


\section{Data collection and organization}

Data were collected from January to May 2015 at different FHS units, according to the participants' working site and their preferences. Interviews lasted 40 minutes on average, were recorded and included closed-ended questions to characterize participants, and open-ended questions focusing on aspects related to health advocacy actions and user's empowerment by PHC nurses.

\section{Data analysis}

Data analysis was based on the transcription of interviews, using the discursive text analysis ${ }^{(16)}$. It was carried out in four stages: unitization of texts; establishment of relationships; capture of the new emerging text; building of a self-organized process. Unitization stood for the researcher's immersion in the transcription of interviews through the deconstruction of texts and their division into units of meaning which were further rewritten to take on the fullest possible meaning. This stage was followed by the coordination of similar meanings, i.e., the process of establishing links or categorization ${ }^{(16)}$.

During categorization, relationships among units of meaning were found and further compared to gather similar elements of meaning in intermediary categories and, then, in two final categories. After capturing the new emerging text, the description and construing of the senses and meanings arising from the text were encompassed, enabling the production of new understandings about the phenomenon of health advocacy and user's empowerment in nursing ${ }^{(16)}$.

\section{RESULTS}

Regarding participants, ages ranged between 25 and 58 years, all women, 12 with a specialization course as their highest degree, three holding a Master's degree. The length of professional experience ranged from 10 to 28 years and length of work as nurses in the FHS ranged from 9 months to 16 years.

Through the analysis of interviews, two categories related to the main barriers and facilitators perceived by nurses during their work in the FHS were identified: (Dis)organization of work, bureaucracy and restrictions in the workplace: when difficulties restrict actions of health advocacy; Overcoming barriers: when the exercise of advocacy starts from personal and collective.

\section{(Dis)organization of work, bureaucracy and limitations in the workplace}

Regarding the barriers to the nurse's work in relation to advocacy in user's health in the FHS scope, the following aspects were highlighted: shortage of material and financial resources; improper facilities that are not welcoming to users; work overload with sharp bureaucratic demand; lack of autonomy of nurses in the workplace; lack of care continuity in $\mathrm{PHC}$ regarding referral/counter-referral issues; lack of political participation of users, focused exclusively on the identification of traditional care models that do not perceive users as a subject with potential to decide what is better to their family, and to their family's and community's health.
A highlight is the low adherence by the community, with little commitment and lack of co-responsibility of users. It has also found professionals without the proper profile to meet the work dynamics in the FHS such as multiprofessional teamwork and consistent exchanges within the team, in addition to professional disengagement of some FHS team members. Shortage of resources was pointed as a barrier that hinders actions of health advocacy by nurses at the FHS, since it hampers or even prevents the development or planning of such actions, demanding significant efforts to perform activities or even prevent them from happening.

So, the shortage of resources available to us really restricts things, and we must do our best to, many times, get almost nothing. (E1).

We could do much more, but we are hindered in everything. There is no vehicle to move in the community, depending on the distance it is really tough. (E7)

Similarly important among the hindering factors to the smooth development of nurses' work as advocators in health in PHC are unsuitable facilities due to lack of space, light or comfort. The inexistence of an adequate physical structure is a barrier to the interactions among nurse, team and users, frequently making users give up from attending the activities scheduled in PHC.

We try to make things that are just beyond the possible but sometimes we miss the structure, there is no space, no material. (E5)

Our development to the group is very hard, there is no place to do it, even here the group of chronic patients meets on Monday afternoon, everyone in a room with no windows, I feel like in an oven, here we miss structure to develop the $d y$ namics, so I always wonder: I'll assemble a group, so you are there doing it, they come once and find this (lack of structure, heat, space) they won't come the second time. (E8)

Work overload, bureaucracy and lack of autonomy have also been mentioned as barriers that impair nurses from performing their actions in the FHS, mainly those related to user's health advocacy. When performing their work, nurses must decide which activities they will perform, and they end up leaving others aside - like the bureaucratic ones - thus worsening the lack of autonomy faced by nurses in given situations - for example, decisions that demand stronger engagement to be executed.

The difficulty is the shortage of personnel, material, and maintenance is also troublesome. We send the order, request and get no return. And the personnel, without personnel it is very difficult. (E10)

By the end we somehow leave the bureaucratic work aside and, then, you have to go after it to meet deadlines, because bureaucracy abounds, because we have the general productivity red tape and that specific to the strategy. (E11) 
Many barriers regarding material and human material, really bureaucratic issue, I guess this is the main impairment to develop the work. (E13)

Nurses must cope with care and administrative issues, many times, and most of the times this administrative and care issues are not restricted to your area, they concern the unit, mainly the administrative unit. So, work overload is prominent. (E8)

The lack of autonomy was also quoted as a barrier for nurses to perform their healthcare action in a comprehensive and decisive way. Despite being familiar with the means to perform their work the respondent nurses stated to find barriers related to the provision of information and care to users, because they have to deal with contradicting decisions by other professionals regarding continuity of the action. This hinders or even prevents their actions, mainly health advocacy and users' empowerment.

Even because something I find... you see... nurses' autonomy in the FHS is very limited, I see that people ask for more, if [I] had more autonomy, everything we must ask the Secretariat. And we are very restricted to the space here. If it is something internal, we can solve, but anything that goes a little beyond it, I have reconsidered. (E6)

So, the nurse's autonomy in the FHS is very limited, it is much more administrative than care-related. Because, sometimes you will render a nursing appointment, you stay there for 30 or 40 minutes with him, and then you spend 30, 40 minutes completing the paperwork. This time you could be listening to them. (E4)

Another highlight in the study was the short effectiveness between referral/counter-referral which disrupts healthcare delivery between services. The respondent nurses stated to refer users to other instances, other levels of complexity, but when the patients return they bring no referral, no feedback on the healthcare provided to them in other services, which would allow more effective continuity of care.

We miss a directed flow where users come, receive care and are referred in that sector, then come back to you with feedback. (E2)

Another negative factor for nurses to serve as health advocators in the FHS is the weak political participation of users. It is worth mentioning that when nurses perform actions on health education and promotion they should share the responsibility of decisions on healthcare with users. However, users usually disregard the need for their political participation, and their responsibility towards their health and community.

We perceive some resistance among the population to adhere to these programs, so we have dropouts, people get exhausted, tired. (E2)

I have tried to implement the local health council, but I just can't do it because they don't perceive the importance. And in other places the council is assembled, claim is present. Here no, I've tried many times, I invite them and nobody wants! (E3)

This community is very engaged, but I guess welfarism is too strong; health education simply doesn't exist with them; they are used to place a responsibility that is not mine, they want me to solve things for them. (E11)

So the community is not interested in fighting for improvements to themselves. (E15)

\section{Facilitators to the exercise of advocacy: when the exercise} of advocacy starts from personal and collective

Among the main facilitators referred to in the study, it is worth mentioning the personal and collective elements that try to cope with the imposed restrictions, such as interaction in the multiprofessional team, adherence of users, professional commitment with the PHC model, establishment of links between users and FHS professionals, and the embracement dynamics. Users' co-responsibility is likely to influence local health issues and also favors more effective health care focused on the community's actual needs.

Regarding facilitators of the nursing work as user's health advocators in the FHS, a highlight is the positive interaction with the multiprofessional team considering that exchanges among professionals foster the planning of different actions on health promotion, prevention and care aimed to improve the local community's quality of life.

I guess that in the FHS what facilitates our work is the team union. Having a group of persons working together, taking things on together. Everybody is working, exchange is really huge. Also, as we work together things are closer, which also facilitates. A core facilitator is to have the team working as a team; this is extremely important to have things working well. (E11)

We work in a team vision, and although each one plays a role, we work focused on the team. (E13)

We take the problem of that person and discuss it with the community agent to get to know the person's involvement with the family, jointly with the physician, the nursing aide, because each team member has a different view of the user. (E4)

Another facilitator of the exercise of health advocacy and users' empowerment by nurses in PHC is the adherence of some users and their active participation in healthcare-related decisions in the unit. Co-responsibility in decision-making is a core factor for health advocacy, since the effective participation of users denotes responsibility with their family's health and theirs, and allows them to exercise their autonomy in healthcare by being active and engaged members in the community.

$I$ guess this team engagement and the active community facilitate the work. (E9)

I recall a woman who didn't want to make use of insulin until she perceived she needed it through our talks to her. 
Today she uses insulin with the syringe and manages it, she took long to adhere, but now she does it. (E10)

I guess this was a great achievement of all of us, the team, because just coming here, attending the appointment and getting the prescription isn't enough; users must be committed. (E4)

Professionals committed to the PHC work model enable health practices and the exercise of user's health advocacy, developing actions in line with the principles of comprehensiveness and community participation, being attentive and available to listen to users, and being knowledgeable.

Here in the strategy we are always available to help, to listen, to clarify doubts. We are available eight hours a day! When they want to talk about personal matters, even if in private, we are totally available. (E14).

I used to keep everything well-organized. So, I have my controls, when I will inform the productivity I check the appointments for the month, so this is something that makes things easier to me. If I want to know how many pregnant women I'm taking care of, it is on the records; if I want to know how many children take childcare, I must have the information always at hand. (E7)

The practices of health advocacy performed by nurses give rise to links between users and the FHS professionals. These links are developed through continuous and local contact, many times even in the home environment, with greater openness and trust among participants, and more effective exchanges focused on the actual needs of the community, which allows providing comprehensive care.

I notice it when they feel at home [health unit] and we also empower them at home. Like in homecare, we enter their homes, knock the door and get into their homes, as we are no strangers we have links with them. Ties are very strong. (E13)

As we continuously perform this work, many times before getting pregnant they have participated through the family planning group, or through a nursing appointment or through the Pap smear test. So, they already have a link and when they come, they participate more frankly, spontaneously, and this proximity enabled by the FHS is very good because we know where they live, it is always the same professional providing care, this facilitates the link and their confidence in the professional as well. (E9)

Professional appraisal facilitates the nurses' actions as health advocators in PHC, and all professionals may share the same room for considerations, insights and opinions about the best conducts in each context:

We see there is no such an image of the physician, of the psychologists, everyone is equal, their participation in the FHS is equally important, it is the technician, the nurse, the physical education teacher, it is the physician, so all have the same importance because we are part of a team. (E2)
The strategy boosts our profession. It allows us, as nurses, to do better for users, as it places you in a multiprofessional team. (E8)

Embracement of users was also mentioned as an important action that enables nurses to exercise health advocacy, as it allows the FHS professionals to get to know and perceive the users' needs as soon as they join the FHS. The priority function of embracement, in addition to improve health care quality, is to expand the establishment of links to work with greater problem-solving capacity.

I try to embrace, build good links, links with the community and use these tools as instruments to improve the user/team relationship. Get to know the person better to be more attentive, sometimes even when in a hurry, listen, effectively apply the strategy of embracement/link to improve this relationship; [users] will come to the health unit more frequently, will have better response to the treatment; sometimes the person resists to recognize a diagnosis, or to try to build links with the unit. (E6)

\section{DISCUSSION}

Among the barriers nurses found when fostering actions of health advocacy and users' empowerment in PHC, there are impairments related to shortage of material and financial resources; unsuitable facilities that hinder carrying out activities with users; work overload added to the sharp bureaucratic demand; nurses' lack of autonomy; traditional healthcare models that hinder the nurses' political work in the community; and, lack of referral/counter-referral in services that interfere in health care continuity.

The shortage of material resources and teams hinders planning actions oriented to users, and the delivery of proper health care to them. As approached in a study with nurses that identified the social representations of vulnerability and empowerment in the context of relationships between professionals and the workplace, there is an antagonism regarding the need to promote proper care and the structural, political, economic and cultural problems found in health, which should be overcome to support and improve healthcare workplaces ${ }^{(17)}$. Despite the nurses' efforts to develop their actions, they find barriers of institutional, technological, political and social nature that weaken professionals in their multiple dimensions ${ }^{(18)}$.

The existence of communication barriers between the different health system levels was also appointed as a restricting factor to the nurses' work as health advocators. To a large extent, this fact is characterized by double or no information between the unit professionals, coordinators and the population, associated with the consistent displacement of FHS nurses to perform managerial activities, which causes work overload ${ }^{(19)}$. Among the barriers to the exercise of health advocacy and users' empowerment by nurses, work overload stands out. It is also related to the unsuitable physical structures and shortage of health professionals, considering that in the absence of team members nurses have to perform other activities that prevent them from fulfilling with quality their core actions of 
promotion, prevention and protection to the health of users in the $\mathrm{FHS}^{(19)}$.

Work overload usually makes nurses cope with moral problems, notably related to feelings of helplessness and lack of autonomy regarding the users' wellbeing ${ }^{(7,20)}$. When delivering healthcare to users, as well as in the issues they advocate on the users' behalf, nurses make their technical-scientific knowledge available and take on the responsibility for decision-making and for their actions $^{(21)}$. However, they may have to deal with impairments imposed by other professionals, healthcare discontinuity regarding referral/counter-referral and the resulting lack of autonomy and moral suffering. However, as health advocators on behalf of users, nurses bear the moral and professional responsibility of challenging, thinking over, defending the user and, whenever required, reporting practices by other professionals that could have negative effects on the patients' healthcare ${ }^{(7,22)}$.

These barriers impair nurses from being politically active in relation to users' healthcare and to the FHS team interactions, preventing them from advocating health issues. The facts presented herein bring the FHS environment closer to the traditional biomedical model adopted by most hospital institutions, where poor relations are translated into fragmented and one-time health actions that effectively disregard the users' uniqueness. It is worth mentioning that the nurses' ${ }^{\prime}$ political action, regarded as a crosscutting knowledge, contributes to provide professionals with a broader view, strong responsibility and commitment as agents of the organizational, social and political change $\mathrm{e}^{(3,20,22)}$.

As the last challenge posed to the exercise of health advocacy by nurses, care fragmentation should be noted. The provision of health care that fails in appraising users as biopsychosocial-cultural beings prevents users from exercising autonomy. Comprehensive health care, in contrast, is a holistic approach of the human being where users are perceived as a whole. To understand health care beyond cure or disease, nurses should take care of people's health as a whole, fostering users' autonomy with an emphasis on the ethics of relationships among all players ${ }^{(21,23)}$.

Regarding facilitators of health advocacy and users' empowerment in the FHS, the study disclosed links among users, nurses and the multiprofessional team that are crucial to promote positive exchanges among players. In this sense, research data are in line with a study carried out in $\mathrm{PHC}$ which approached health promotion and community participation in the search for better health results, which evidenced the important role played by the coordination between the community and the FHS team professionals to promote health, notably the community engagement and interest to participate in organized local groups ${ }^{(24)}$.

Community participation in health issues leads to the promotion of community health. Still in the interactions with the community, the FHS team's work mediates interpersonal relationships among professionals, users and communities with high indexes of adherence, through the participatory management of community actions consolidated through the community's interest to to sustain and qualify them in terms of work conditions ${ }^{(24)}$.

Another crucial factor for nurses as community advocators is the embracement of users at the services' entry door.
Embracement, as a strategic tool, is completely opposite to the biomedical model that prevailed for decades as the only option, without meeting the population's actual needs since it is characterized by individualized service focused on the complaint, biological aspects, care fragmentation having the hospital as the main health care setting ${ }^{(21,25)}$.

Embracement recalls issues of workplace organization with an emphasis on the ethical and political dimensions of professionals in contact with users, as well as on the reformulation of the health care and managerial model to facilitate access to the service offered, to relax and expand clinical care and favor interdisciplinary care $^{(26)}$. Embracement considers the spoken and non-spoken needs of users so that workers and users can focus on actions aimed at their singularities, with guidance on how to do them, demanding the multiprofessional team to use other technologies that allow the incorporation of users into actions, as it fosters and maximizes an individual's autonomy in health care production ${ }^{(27)}$.

The work of FHS nurses causes mutual fulfillment of the basic human needs in the interaction established between these professionals and representatives of local groups organized to allow the effective implementation of participatory management in health. Nurses step into the complexity of local health determinants, advancing in terms of solving community problems ${ }^{(24,28)}$. Moreover, nurses are acknowledged for their huge potential to manage the FHS, contributing to enhance the reliability and visibility of nursing as a reference in health care to the community. As such, nurses can exercise their professional autonomy and enhance their own satisfaction, as well as that of the team and users, increasing the profession visibility.

\section{Study limitations}

The limitations of this study are regard the fact that it was performed in one single context. This evidences the need for new studies at other sites to verify whether these barriers and facilitators occur in other health spaces considering that this study was performed in one single city and in the Brazilian context.

\section{Contributions to nursing}

The study found that nurses committed to health advocacy can positively intervene in the improvement of the community's health, mainly in issues related to users' empowerment.

\section{FINAL CONSIDERATIONS}

This study disclosed the barriers and facilitators that nurses find when exercising health advocacy and users' empowerment in primary health care, emphasizing the important role of this action to foster the community's defense and autonomy. Most of the barriers faced in the nurses' work are physical and material such as unsuitable structure, shortage of human and material resources, in addition to work overload. As regards the facilitators found, the most relevant ones related to: links built between professionals and the community; mutual respect; collective participation in discussions and interventions on health; professional commitment; and, embracement as a unique moment in PHC to get nurses closer to users. 
The establishment of advocacy in primary health care by nurses passes by the need to change their attitudes, taking on their autonomy, singular knowledge and core role in health spaces, in an attempt to associate nurses' care actions and the establishment of affective links, and to strengthen citizenship and the social rights of users.

\section{REFERENCES}

1. Spagnuolo RS, Bocchi SCM. [Between the processes of strengthening and weakening of the Family Health Strategy]. Rev Bras Enferm [Internet]. 2013[cited 2015 Nov 02];66(3):366-71. Available from: http://www.scielo.br/pdf/reben/v66n3/a10v66n3.pdf Portuguese

2. Silva KM, Santos SMA. The nursing process in family health strategy and the care for the elderly. Texto Contexto Enferm[Internet]. 2015[cited 2015 Nov 15];24(1):105-11. Available from: http://www.scielo.br/pdf/tce/v24n1/0104-0707-tce-24-01-00105.pdf

3. Pereira PJ, Bourget M. Família: representações sociais de trabalhadores da Estratégia Saúde da Família. Saúde Soc [Internet]. 2010[cited 2015 Apr 10];19(3):584-91. Available from: http://www.revistas.usp.br/sausoc/article/view/29672/31544

4. Costa RKS, Miranda FAN. O enfermeiro e a estratégia saúde da família: contribuição para a mudança do modelo assistencial. Rev Rene [Internet]. 2012[cited 2015 May 21];9(2):120-8. Available from: http://www.revistarene.ufc.br/revista/index.php/revista/ article/view/570/pdf

5. Mascarenhas NB, Melo CMM, Fagundes NC. [Production of knowledge on health promotion and nurse's practice in Primary Health Care]. Rev Bras Enferm [Internet]. 2012[cited 2015 Oct 14];65(6):991-9. Available from: http://www.scielo.br/pdf/reben/ v65n6/a16v65n6.pdf Portuguese

6. Hanks RG. The medical-surgical nurse perspective of advocate role. Nurs Forum [Internet]. 2010[cited 2015 Sep 08];45(2):97107. Available from: http://onlinelibrary.wiley.com/doi/10.1111/j.1744-6198.2010.00170.x/epdf

7. Barlem ELD Lunardi LV, Lunardi GL, Dalmolin GL, Tomaschewski JG. Vivência do sofrimento moral na enfermagem: percepção da enfermeira. Rev Esc Enferm USP [Internet]. 2012[cited 2015 Sep 10];46(3):681-8. Available from: http://www.revistas.usp.br/ reeusp/article/view/40997/44530

8. Hanks RG. Social Advocacy: a call for nursing action. Pastoral Psychol[Internet]. 2013[cited 2015 Nov 05];62(2):163-73. Available from: http://link.springer.com/article/10.1007/s11089-011-0404-1\#/page-1

9. Barlem ELD, Lunardi VL, Lunardi GL, Tomaschewski-Barlem JG, Silveira RS, Dalmolin GL. Moral distress in nursing personnel. Rev Latino-Am Enfermagem [Internet]. 2013[cited 2015 Sep 25];21(Spec):79-87. Available from: http://www.scielo.br/pdf/rlae/ v21nspe/11.pdf

10. Cole C, Wellartd S, Mummery J. Problematizing autonomy and advocacy in nursing. Nurs Ethics [Internet]. 2014 [cited 2015 Dec 10];21(5):576-82. http://nej.sagepub.com/content/21/5/576.full.pdf + html

11. Ventura CAA, Mello DF, Andrade RD, Mendes IAC. [Nursing partnership with users in the defense of SUS]. Rev Bras Enferm [Internet]. 2012[cited 2014 Apr 15];65(6):893-8. Available from: http://www.scielo.br/pdf/reben/v65n6/a02v65n6.pdf Portuguese

12. Pereira RCA, Rivera FJU, Artmann E. The multidisciplinary work in the family health strategy: a study on ways of teams. Interface[Internet]. 2013[cited 2015 Nov 10];17(45):327-40. Available from: http://www.scielo.br/pdf/icse/v17n45/aop0613.pdf

13. Roecker S, Nunes EFPA, Marcon SS. O trabalho educativo do enfermeiro na Estratégia Saúde da Família. Texto Contexto Enferm [Internet]. 2013[cited 2015 Oct 11];22(1):157-65. Available from: http://www.scielo.br/pdf/tce/v22n1/pt_19.pdf

14. Salci MA, Maceno P, Rozza SG, Silva DMGV, Boehs AE, Heidemann ITSB. Educação em saúde e suas perspectivas teóricas: algumas reflexões. Texto Contexto Enferm [Internet]. 2013[cited 2015 Oct 11];22(1):224-30. Available from: http://www.scielo. br/pdf/tce/v22n1/pt_27.pdf

15. Vaartio H, Leino-Kilpi H, Suominen T, Puukka P. Nursing Advocacy in procedural pain care. Nurs Ethics [Internet]. 2009[cited 2015 Dec 01];16(3):340-62. Available from: http://dx.doi.org/10.1177/0969733009097992

16. Moraes R, Gagliazzi MC. Análise textual discursiva. 2a ed. Ijuí: Unijuí; 2013.

17. Santos EI, Gomes AMT, Oliveira DC. Representações da vulnerabilidade e do empoderamento por enfermeiros no contexto da AIDS. Texto Contexto Enferm [Internet]. 2014[cited 2015 Mar 22];23(2):408-16. Available from: http://www.scielo.br/pdf/tce/ v23n2/pt_0104-0707-tce-23-02-00408.pdf

18. Oliveira RM Leitao IMTA, Aguiar LL, Oliveira ACS, Gazos DM, Silva LMS. Evaluating the intervening factors in patient safety: focusing on hospital nursing staff. Rev Esc Enferm [Internet]. 2015[cited 2015 Mar 03];49(1):104-13. Available from: http://www. scielo.br/pdf/reeusp/v49n1/0080-6234-reeusp-49-01-0104.pdf

19. Lanzoni GMM, Meirelles BHS. [Nurse leadership: intervening element in the relationships network of the community health care agente]. Rev Bras Enferm [Internet]. 2013[cited 2014 Dec 02];66(4):557-63. Available from: http://www.scielo.br/pdf/reben/ v66n4/v66n4a14.pdf Portuguese

20. Aitamaa E, Leino-Kilpi H, Puukka P, Suhonen R. Ethical problems in nursing management: the role of codes of ethics. Nurs Ethics 
[Internet]. 2010[cited 2015 Nov 10];17(4):469-82. Available from: http://nej.sagepub.com/content/17/4/469.full.pdf + html

21. Persegona KR, Rocha DLB, Lenardt MH, Zagonel IPS. O conhecimento político na atuação do enfermeiro. Esc Anna Nery Rev Enferm [Internet]. 2009[cited 2015 Jun 19];13(3):645-50. Available from: http://www.scielo.br/pdf/ean/v13n3/v13n3a27.pdf

22. Baratieri T, Marcon SS. Longitudinalidade no trabalho do enfermeiro: identificando dificuldades e perspectivas de transformação. Texto Contexto Enferm [Internet]. 2012[cited 2014 Dec 02];21(3):549-57. Available from: http://www.scielo.br/pdf/tce/v21n3/v21n3a09.pdf

23. Sanz GL. La autonomía del paciente y la responsabilidad del personal de enfermería. ENE Revista de Enfermería [Internet]. 2013[cited 2015 Nov 17];7(1):1-5. Available from: http://www.ene-enfermeria.org/ojs/index.php/ENE/article/view/211/pdf_1

24. Cardoso LS, Cezar-Vaz MR, Costa VZ, Bonow CA, Almeida MCV. Promoção da saúde e participação comunitária em grupos locais organizados. Rev Bras Enferm [Internet]. 2013[cited 2015 Sep 01];66(6):928-34. Available from: http://www.scielo.br/pdf/ reben/v66n6/18.pdf

25. Marin MJS, Marchioli M, Moracvick M. Fortalezas e fragilidades do atendimento nas unidades básicas de saúde tradicionais e da estratégia de Saúde da Família pela ótica dos usuários. Texto Contexto Enferm [Internet]. 2013[cited 2015 Aug 10];22(3):780-8. Available from: http://www.scielo.br/pdf/tce/v22n3/v22n3a26.pdf

26. Silva CS, Paes NA, Figueiredo TMRM, Cardoso MAA, Silva ATMC, Araújo JSS. Controle pressórico e adesão/vinculo em hipertensos usuários da Atenção Primária a Saúde. Rev Esc Enferm USP [Internet]. 2013[cited 2015 May 05];47(3):584-90. Available from: http://www.scielo.br/pdf/reeusp/v47n3/0080-6234-reeusp-47-3-00584.pdf

27. Lopes GVD, Dourado O, Menezes TMO, Miranda AC, Araújo KL, Guimarães ELP. Acolhimento: quando o usuário bate à porta. Rev Bras Enferm [Internet]. 2014[cited 2015 Apr 02];67(1):104-10. Available from: http://www.scielo.br/pdf/reben/v67n1/00347167-reben-67-01-0104.pdf

28. Marques IP, Rezende K, Chiari MF. O desafio do trabalho na estratégia de saúde da família na perspectiva do trabalhador. Atas CIAIQ2015 [Internet]. 2015[cited 2015 Dec 11];1(1):529-32. Available from: http://proceedings.ciaiq.org/index.php/ciaiq2015/ article/view/121/117 